\title{
Late Viséan pelagic chondrichthyans from northern Europe
}

Michał Ginter, Christopher J. Duffin, Mark T. Dean, and Dieter Korn

Acta Palaeontologica Polonica 60 (4), 2015: 899-922 doi:http://dx.doi.org/10.4202/app.00084.2014

The relatively rich assemblages of shark teeth from pelagic limestone (Mississippian, late Viséan, late Asbian-middle Brigantian) of three northern European regions: the Rhenish Mountains (Westenfeld Quarry, Germany), the Holy Cross Mountains (Todowa Grząba at the edge of Ostrówka Quarry, Poland), and Derbyshire (Cawdor Quarry, Matlock, England, UK) display certain similarities, with the absolute predominance of the teeth of Falcatidae (small Symmoriiformes) and the constant presence of Thrinacodus spp. The largest and most diverse assemblage from Todowa Grząba contains at least three species of a falcatid Denaea, a xenacanthimorph Bransonella nebraskensis, a newly described phoebodontid Thrinacodus dziki sp. nov., a few ctenacanthiform and euselachian teeth, and two abraded euchondrocephalan dental elements. Anachronistidae, common in the most of late Viséan pelagic faunas, are absent from Todowa Grząba and Westenfeld. The material under study differs from the shallow-water chondrichthyan fauna, hitherto described from the Mississippian carbonate platform facies, by its taxonomic content (particularly almost total absence of Euchondrocephali), generally lower diversity, and higher frequency of small teeth.

Key words: Chondrichthyes, teeth, Carboniferous, Mississippian, England, Germany, Poland.

Michał Ginter [m.ginter@uw.edu.pl], Institute of Geology, University of Warsaw, Żwirki i Wigury 93, 02-089 Warszawa, Poland; Christopher J. Duffin [cduffin@blueyonder.co.uk], Palaeontology Section, Earth Science Department, The Natural History Museum, Cromwell Road, London SW7 5BD, UK and 146, Church Hill Road, Sutton, Surrey SM3 8NF, England, UK; Mark T. Dean, formerly British Geological Survey, Edinburgh, Scotland, UK; Dieter Korn [dieter.korn@mfn-berlin.de], Museum für Naturkunde, Leibniz Institute for Evolution and Biodiversity Science, Invalidenstrasse 43, 10115 Berlin, Germany. 
distribution, and reproduction in any medium, provided the original author and source are credited.

For Full text $(1,683.9 \mathrm{kB})$ 